\title{
ZAGOSPODAROWANIE UŻYTKÓW ROLNYCH NA ZABUDOWANYCH TERENACH MIESZKANIOWYCH AGLOMERACJI POZNANSKIEJ
}

Zarys treści Artykuł porusza kwestię sposobu zagospodarowania użytków rolnych pozostałych na zabudowanych terenach mieszkaniowych aglomeracji poznańskiej. Poprzez identyfikację zabudowanych działek budowlanych, na których zgodnie z zapisami ewidencji gruntów i budynków, nadal znajdują się fragmenty użytków rolnych oraz inwentaryzację faktycznego sposobu ich użytkowania wykazano, że grunty te w zdecydowanej większości nie są użytkowane rolniczo, a wykorzystywane przede wszystkim jako tzw. tereny zielone, tj. głównie trawniki i tereny rekreacyjne, którym towarzyszą obce gatunkowo nasadzenia. Potwierdzono tym samym powszechnie obserwowany zanik występowania tradycyjnego ogrodu wiejskiego.

Słowa kluczowe Grunt rolny, suburbanizacja, zabudowane tereny mieszkaniowe, krajobraz wiejski.

\section{Wprowadzenie}

Od początku transformacji ustrojowej w Polsce obserwuje się systematyczny spadek powierzchni użytków rolnych. Następuje on głównie na skutek wyłączania gruntów rolnych z produkcji rolniczej na cele inwestycyjne. Dominujący kierunek tych wyłączeń stanowi przekształcanie użytków rolnych w tereny osiedlowe. Proces ten w największym stopniu dotyczy obszarów wiejskich znajdujących się w bliskim sąsiedztwie dużych ośrodków miejskich. W efekcie, wsie położone na obszarach metropolitalnych sukcesywnie tracą swój wiejski charakter, zarówno pod względem pełnionych funkcji gospodarczych, struktury mieszkańców, jak i charakteru krajobrazu (por. Bański 2005; Lisowski i in. 2007; Maćkiewicz 2007, 2011; Wójcik 2008; Kacprzak, Staszewska 2009, 2011; Kacprzak, Maćkiewicz 2011; Kajdanek 2012; Maćkiewicz 2016; Śleszyński 2016). Jednocześnie wobec 
braku konsekwencji w przepisach dotyczących ochrony gruntów rolnych i leśnych, ochrony krajobrazu, planowania i zagospodarowania przestrzennego, gospodarki nieruchomościami oraz ewidencji gruntów i budynków, gospodarka gruntami na tych obszarach często była i jest prowadzona w sposób nieracjonalny. Przyczynia się to m.in. do nadmiernej i bezpowrotnej utraty gruntów rolnych, w tym także tych o wysokich klasach bonitacyjnych, rozwoju rozproszonego budownictwa mieszkaniowego, zatracania wiejskiego krajobrazu, jak również utrudnień w ustaleniu faktycznej powierzchni użytkowanych rolniczo gruntów, a w konsekwencji prawidłowego ich opodatkowania (Kacprzak, Maćkiewicz 2013; Maćkiewicz, Motek 2014; Maćkiewicz, Kacprzak 2015). Postępującemu zanikowi specyficznych cech krajobrazu wiejskiego sprzyja brak odrębnego aktu prawnego, który szczegółowo regulowałby kwestie związane z kształtowaniem terenów zieleni, a tym samym zieleni przydomowej. Analiza aktów prawnych w zakresie pojęcia „tereny zieleni” pozwala stwierdzić, że jest ono jednym z mniej precyzyjnych terminów stosowanych w polskim planowaniu przestrzennym. Sprawy dotyczące zieleni pośrednio reguluje kilka ustaw, niestety akty te nie uzupełniają się i traktują o zieleni niezależnie, zawierając szereg luk [por. Ustawa z dnia 7 lipca 1994 roku Prawo Budowlane (Dz.U. 2016, nr 0, poz. 290, z późn. zm.), Ustawa z dnia 16 kwietnia 2004 roku o ochronie przyrody (Dz.U. 2016, nr 0, poz. 2134, z późn. zm.), Ustawa z dnia 27 marca 2003 roku o planowaniu i zagospodarowaniu przestrzennym (Dz.U. 2016, nr 0, poz. 778, z późn. zm.), Ustawa z dnia 27 kwietnia 2001 roku Prawo ochrony środowiska (Dz.U. 2001, nr 62, poz. 627, z późn. zm.)]. Ponadto, w Rozporzadzeniu Ministra Infrastruktury w sprawie warunków technicznych, jakim powinny odpowiadać budynki i ich usytuowanie (Dz.U. 2015, poz. 1422) znajdują się zapisy dotyczące tzw. powierzchni biologicznie czynnej, co dodatkowo komplikuje sytuację. Taki stan prawny powoduje, że zieleń jest niezobowiązującym i często niewygodnym elementem planowania przestrzennego w Polsce. Obecnie większość decyzji dotyczących charakteru i jakości przestrzeni podejmowana jest w oparciu o gminne dokumenty planistyczne. Niestety, na poziomie lokalnego planowania przestrzennego zapisy odnoszące się do zieleni pojawiają się incydentalnie i zwykle ogólnikowo dotyczą: formy (np. zieleń publiczna, izolacyjna lub zieleń niska lub wysoka), charakteru (zieleń ozdobna, mieszana, zimozielona itp.) lub wyposażenia. Jednocześnie należy zwrócić uwagę na faktyczny brak wytycznych w zakresie składu gatunkowego projektowanej zieleni.

Celem opracowania jest inwentaryzacja i rozpoznanie sposobu zagospodarowania fragmentów użytków rolnych pozostających w granicach zabudowanych działek mieszkaniowych $\mathrm{w}$ aglomeracji poznańskiej. Szczególną uwagę zwrócono na charakter nasadzeń występujących na tego rodzaju gruntach oraz ich związek z tradycyjnym krajobrazem polskiej wsi. Studium przypadku (case study) dotyczyło, położonego w graniczącej od północnego zachodu z Poznaniem gminie wiejskiej Rokietnica, obrębu ewidencyjnego Bytkowo. W oparciu o dane 
z ewidencji gruntów i budynków, zawierające informacje o strukturze i powierzchni poszczególnych rodzajów użytków gruntowych wchodzących w skład pojedynczych działek ewidencyjnych, dokonano identyfikacji przypadków występowania na jednej działce zabudowanych terenów mieszkaniowych oraz fragmentów użytków rolnych. Następnie zbiór działek ewidencyjnych ograniczono do tych, których powierzchnia nie przekraczała $1000 \mathrm{~m}^{2}$, tzn. takich, które jednoznacznie spełniały kryteria zabudowanych domami mieszkalnymi działek budowlanych. W dalszym etapie postępowania badawczego z wykorzystaniem ortofotomapy, przeprowadzono wstępną analizę zagospodarowania znajdujących się na poszczególnych działkach fragmentów gruntów rolnych. Pozyskane w ten sposób informacje zweryfikowano następnie podczas bezpośredniej inwentaryzacji terenu. Badania przeprowadzono wykorzystując głównie informacje pozyskane z Ewidencji Gruntów i Budynków Powiatowego Ośrodka Dokumentacji Geodezyjnej i Kartograficznej w Poznaniu, dane dostępne w Systemie Informacji Przestrzennej gminy Rokietnica, jak również materiały własne pozyskane w wyniku wizyty w terenie.

\section{Tradycyjny ogród jako element krajobrazu wiejskiego}

Istotnym zagadnieniem podejmowanym w literaturze krajobrazu obszarów wiejskich jest komponowanie zieleni w oparciu o rodzime gatunki roślin, z utrzymaniem dominacji zieleni wysokiej nad zabudową oraz zachowanie i przywracanie tradycyjnych form zieleni wiejskiej, w tym ogródków przydomowych (Bogdanowski 1976; Borcz 2005; Niedźwiecka-Filipiak 2005; Cała, Orzechowska 2007; Majdecka-Strzeżek 2009; Mitkowska 2009; Pietrzak, Angiel 2009; Chojnacka i Wilkaniec 2011; Uruszczak 2012; Marks i in. 2012). Ogrody od wieków towarzyszyły siedzibom ludzkim, stanowiąc obraz ówczesnych potrzeb społecznych i panujących poglądów artystycznych, ich kształtowanie zależne było także od kultury, obyczajów i wierzeń danego społeczeństwa (Majdecki 2009). W historii polskich ogrodów szczególnie dobrze udokumentowana jest tradycja użytkowych ogrodów przyklasztornych i ozdobnych ogrodów towarzyszących rezydencjom magnackim i dworom szlacheckim. Natomiast informacje dotyczące ogrodów wiejskich są stosunkowo skromne ze względu na brak trwałych elementów tego ogrodu, które mogłyby się zachować oraz ustnie przekazywaną z pokolenia na pokolenie wiedzę o jego uprawie. Za początki pierwszych ogrodów chłopskich można uznać niewielkie działki przydzielone w XIII wieku bezrolnym chłopom jako istotne źródło ich wyżywienia (Baranowski 1964). Do niedawna podstawowym składnikiem krajobrazu otwartego była zabudowa zagrodowa skupiająca budynki mieszkalne, gospodarcze, inwentarskie oraz towarzysząca im roślinność - synantropijna, jak i celowo sadzona. Ogrody wiejskie dzięki swej skromnej formie, podyktowanej względami praktycznymi oraz tradycją uprawy, harmonijnie 
wtapiały się w otaczający krajobraz. Wysokie drzewa liściaste równoważyły bryły budynków, często dominując w panoramie wsi. Przy domostwach, zwykle w pobliżu bramy wjazdowej na podwórze, sadzono pojedyncze drzewo lub pary drzew, upamiętniając moment osiedlenia się lub narodzin potomstwa. Dodatkowo pełniły one symboliczną rolę „opiekunów” domostwa, w upalne dni ocieniając zabudowania i podwórze, a w czasie burz chroniąc przed piorunami i pożarem. Natomiast w przestrzeni wsi, wysokie, pojedyncze drzewa stanowiły swoistego rodzaju punkty orientacyjne i drogowskazy. Dobór gatunków warunkowały tradycje regionalne, jednak do najczęściej stosowanych w zagrodach drzew należały użytkowe i miododajne, m.in. lipa, klon, jawor, kasztanowiec i dąb. Uzupełniająco, zwykle wzdłuż granicy działki, sadzono krzewy chroniące jej mieszkańców przed wiatrem, kurzem i hałasem. Do najpopularniejszych gatunków należały: lilak pospolity, jaśminowiec wonny, kalia koralowa, czarny bez oraz róże. Charakterystyczny dla przestrzeni zagrodowej był także gaik - miejsce ocienione drzewami i porośnięte trawą, sprzyjające wypoczynkowi w upalne dni. Szczególną rolę w przestrzeni wsi pełniły sady, a w nich jabłonie, grusze i śliwy oraz nieodłączne pasieki. Sady najczęściej usytuowane pomiędzy zagrodą a rozłogiem pól, przesłaniały mniej atrakcyjne zaplecze gospodarskie, pozostawiając widoczne w panoramie wsi jedynie dachy zabudowań. Przez stulecia przydomowy ogród wiejski miał wyłącznie użytkowe funkcje, dostarczał pożywienia, przypraw i leków, a ponieważ podstawowym uprawianym warzywem była kapusta, często nazywano je kapustnikami (Topolski 1964). Uprawa kapusty, rzepy, lnu i zbóż stanowiła istotne źródło wyżywienia rodzin chłopskich, natomiast szyszki chmielu były przeznaczone na dziesięcinę kościelną (Baranowski 1964). Pod koniec XVII i na początku XVIII wieku, w miarę poprawiana się sytuacji bytowej mieszkańców wsi oraz pod wpływem rozwoju ogrodów przy dworach szlacheckich, rezydencjach magnackich oraz posiadłościach kościelnych, a tym samym lepszej dostępności do materiału roślinnego, coraz więcej miejsca w zagrodzie zaczęły zajmować rośliny ozdobne. Duże znaczenie miało także uwłaszczenie - przydzielone zabudowania grodzono plecionkami wiklinowymi, później parkanami z żerdzi lub sztachet. Przestrzeń między domem a drogą biegnącą przez wieś, tzw. przedogródek, ogródek podokienny, frontowy lub po prostu kwiatowy, obsadzano wielobarwnymi kwiatami. Rośliny wyższe, takie jak: malwy, ostróżki, rudbekie, kosmosy, floksy, dalie, słoneczniki, liliowce i kosaćce sadzono zwykle przy ogrodzeniach lub zamiast nich, aby były lepiej widoczne. Do najczęściej spotykanych gatunków o wyrazistych kolorach, miododajnych i pachnących należały: rezeda, ruta, wieczornik, maciejka, mak, orlik pospolity, chryzantema, serduszka, omieg, dzielżan, łubin, lepnica, pysznogłówka, wiesiołek, piwonia, pierwiosnek, przebiśnieg, lwia paszcza, nagietek lekarski, stokrotka, goździk, eszolcja, kocanka, lewkonia, ślazówka, dziewanna, cynia, aksamitka. W ogródkach podokiennych czasami sadzono także krzewy i pnącza, dekorując nimi wejście na ganek 
lub zasłaniając ściany. Wśród nich należy wymienić: róże, lilaki, jaśminowce, dzikie wino oraz powojniki (Chowaniec 1964). Przestrzeń przedogródka stanowiła wizytówkę zagrody, zapraszała do obejścia, zaś bogactwo roślin ozdobnych świadczyło o zamożności gospodarzy i pracowitości gospodyni. Uprawiane kwiaty zdobiły zagrodę, ale jednocześnie były przeznaczone do bukietów, którymi dekorowano obrazy o tematyce religijnej, przydrożne kapliczki i kościelne ołtarze (Topolski 1964). Wielkość i kształt przedogródka były zróżnicowane w zależności od regionu geograficznego. Na Kurpiach przeważały geometryczne rabaty i grządki, zaś na Mazurach i Pomorzu układ roślin był bardziej luźny i nawiązujący do nasadzeń naturalistycznych, w Wielkopolsce spotykano symetryczne dywany kwiatowe, w kształcie kwadratu z kołem w środku obwiedzione strzyżonym bukszpanem (Plessner 1987). Z czasem kwatery z klombami otaczano także bielonymi polnymi kamieniami, brzozowymi płotkami, dachówkami lub ułożonymi skośnie cegłami. W ogrodach podokiennych nadal uprawiano rośliny użytkowe - szczególnie ceniono te o właściwościach leczniczych i przyprawowych oraz silnym aromacie, przypisując im magiczną moc. Do często spotykanych należały m.in. lubczyk, hyzop, szałwia i ruta. Nieodłącznym składnikiem ogrodu były rośliny związane z obrzędowością i kultem religijnym. Do dziś zachowała się tradycja święcenia bukietów zielnych na święto Matki Boskiej Zielnej oraz Boże Ciało. Według wierzeń miały one uchronić plony od nieszczęść burzowych i gradowych. Taką rolę pełniła: leszczyna, bylica boże drzewko, kopytnik. Osobną grupę roślin stanowiły zioła świętojańskie: lulek czarny, łopian, bób, dziurawiec, pokrzywa, brzoza, olsza czarna. Ich celem było ustrzec ludzi, zwierzęta i plony przed urokami czarownic, chorobami i klęskami żywiołowymi (Czechowicz, Kozłowska 2004). Specyficzna symbolika roślin oraz ich „nadprzyrodzone” moce towarzyszyły człowiekowi - gospodarzowi na każdym etapie jego życia: od narodzin i czasu dzieciństwa, przez małżeństwo i dojrzałość, aż po starość i śmierć (Zaraś-Januszkiewicz i in. 2004). Współcześnie wizerunek wiejskich ogrodów bardzo się zmienia. Funkcja użytkowa ustępuje miejsca ozdobnej oraz rekreacyjnej. $Z$ powodów praktycznych ogranicza się dobór gatunków i nasadzeń na rzecz powierzchni trawiastych. Zaciera się również, widoczna w dawnych wiejskich ogrodach, symbolika roślin. Coraz bardziej zaznacza się niekorzystne zjawisko unifikacji ogrodu miejskiego i wiejskiego (Marks i in. 2012).

\section{Użytki rolne na zabudowanych działkach budowlanych}

W Polsce dopuszczalną i powszechną praktyką związaną z zabudowywaniem nowych terenów jest stosowanie jedynie częściowych wyłączeń gruntów rolnych z produkcji rolniczej (Maćkiewicz i Motek 2014). W konsekwencji, nierzadko fragmenty powierzchni działek zabudowanych domami mieszkalnymi stanowią tereny sklasyfikowane w ewidencji gruntów i budynków jako użytki rolne (ryc. 1, 
ryc. 2). Głównej przyczyny takiego stanu rzeczy należy upatrywać w możliwości bezpłatnego wyłączenia z produkcji rolniczej gruntu rolnego o powierzchni do $500 \mathrm{~m}^{2}$, jak również różnicy w wysokości stawek podatkowych [por. Ustawa $z$ dnia 3 lutego 1995 roku o ochronie gruntów rolnych i leśnych (Dz.U. 2015, poz. 909, z późn. zm.), Ustawa z dnia 12 stycznia 1991 roku o podatkach i opłatach lokalnych (Dz.U. 2016, poz. 716, z późn. zm.), Ustawa z dnia 15 listopada 1984 roku o podatku rolnym (Dz.U. 2016, poz. 617, z późn. zm.)]. Za grunt rolny odprowadzany jest bowiem podatek rolny, którego wysokość jest znacznie niższa od obowiązującego, w przypadku terenów sklasyfikowanych jako B - zabudowane tereny mieszkaniowe, podatku od nieruchomości. Dlatego też nierzadko można spotkać się z sytuacją, gdy na działce ewidencyjnej powierzchnia zabudowanych terenów mieszkaniowych niemalże pokrywa się z obrysem budynku, a pozostała część terenu pozostaje nadal terenem rolnym (ryc. 2). Skutki takiej praktyki trzeba ocenić negatywnie. Poprzez ograniczenie kosztu wyłączenia gruntu rolnego z produkcji rolnej, prowadzi ona do nieracjonalnego gospodarowania gruntami, a także umniejsza dochody budżetów gmin z podatku od nieruchomości (Maćkiewicz i Motek 2014). Postępowanie takie jest tym bardziej szkodliwe, że de facto nie ma żadnych restrykcji dotyczących zagospodarowania pozostającego na zabudowanej działce budowlanej fragmentu użytku rolnego, który często jedynie teoretycznie, dla celów fiskalnych, pozostaje terenem użytkowanym rolniczo. Dzieje się tak, ponieważ właściciele tego rodzaju gruntów zazwyczaj zdają się nie zauważać związku pomiędzy zapisami ewidencji gruntów i budynków a sposobem użytkowania fragmentu działki - zazwyczaj większej części ogrodu, za który odprowadzają podatek rolny.

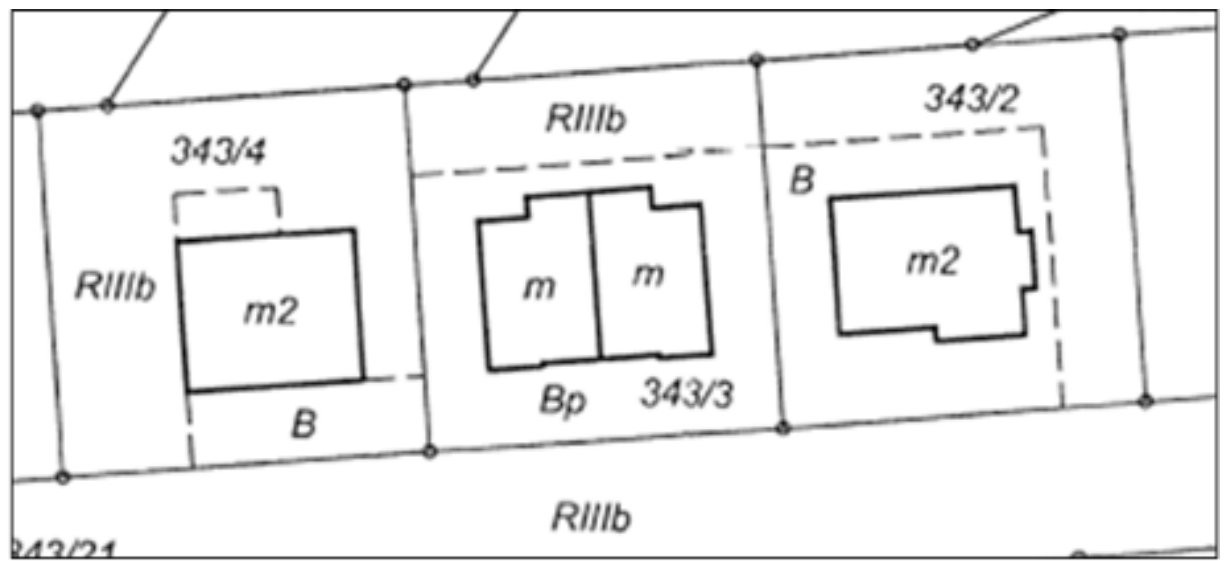

Ryc. 1. Użytki rolne na zabudowanych działkach budowlanych w obrębie ewidencyjnym Bytkowo

Źródło: Ewidencja Gruntów i Budynków

Powiatowy Ośrodek Dokumentacji Geodezyjnej i Kartograficznej w Poznaniu 


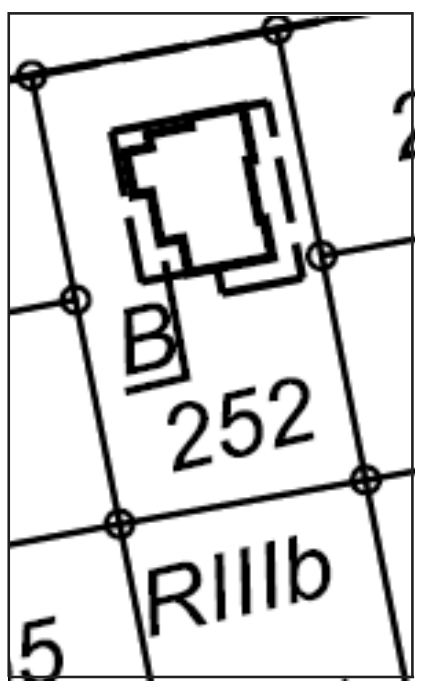

Ryc. 2. Przykład praktyki wyłączania jak najmniejszej powierzchni działki budowlanej z użytkowania rolniczego - obręb ewidencyjny Bytkowo

Źródło: Ewidencja Gruntów i Budynków Powiatowy Ośrodek Dokumentacji Geodezyjnej i Kartograficznej w Poznaniu

Badanie działek ewidencyjnych o powierzchni do $1000 \mathrm{~m}^{2}$ pod kątem struktury użytków gruntowych przeprowadzone w obrębie Bytkowo wykazało, że na ponad połowie $(55,95 \%)$ ze 150 działek, obok terenów mieszkaniowych, występowały grunty sklasyfikowane w ewidencji gruntów i budynków jako użytki rolne. Oznacza to, że częściej niż na co drugiej zabudowanej działce budowlanej, obok terenów mieszkaniowych, znajdowały się użytki rolne. Ponadto ich udział w łącznej powierzchni analizowanych działek był znaczny i wynosił $27,83 \%$ areału (tab. 1). Należy przy tym podkreślić, że zdecydowaną większość użytków rolnych wchodzących w skład zabudowanych działek budowlanych stanowiły grunty orne o wysokiej, szczególnie jak na warunki powiatu poznańskiego, klasie bonitacji - IIIb.

Tabela 1

Użytki gruntowe na zabudowanych działkach budowlanych w obrębie ewidencyjnym Bytkowo

\begin{tabular}{ccc}
$\begin{array}{c}\text { Oznaczenie } \\
\text { i klasa użytku }\end{array}$ & Rodzaj użytku & $\begin{array}{c}\text { Powierzchnia } \\
{[\text { ha] }}\end{array}$ \\
\hline B & tereny mieszkaniowe & 4,4656 \\
\hline ŁV & łąki & 0,0267 \\
\hline RIIIa & grunty orne & 0,2304 \\
\hline RIIIb & grunty orne & 1,0743 \\
\hline RIVa & grunty orne & 0,3911 \\
\hline & Razem & 6,1881 \\
\hline
\end{tabular}

Źródło: B. Maćkiewicz, P. Motek (2014). 


\section{Zagospodarowanie użytków rolnych na zabudowanych działkach budowlanych}

Jak wcześniej wspomniano, udział użytków rolnych w ogólnej powierzchni zabudowanych działek budowlanych w obrębie Bytkowo był znaczny i w dużej mierze dotyczył gruntów dobrej jakości. W celu identyfikacji sposobu ich zagospodarowania, dokonano bezpośredniej inwentaryzacji terenu, podczas której treść mapy katastralnej porównano z faktycznym użytkowaniem gruntu. Wykazała ona, że na zdecydowanej większości działek $(85,71 \%)$, użytki rolne zagospodarowano jako trawniki i tereny rekreacyjne (fot. 1, fot. 2). Jedynie w bardzo nielicznych przypadkach, tj. na trzech działkach zabudowanych budynkami mieszkalnymi, pozostające w ich granicach użytki rolne były przynajmniej częściowo wykorzystywane pod uprawę warzyw i owoców (fot. 3, fot. 4). Oznacza to, że zagospodarowanie użytków rolnych na zabudowanych działkach budowlanych w zdecydowanej większości przypadków jest niezgodne z zapisami ewidencji gruntów i budynków - katastru nieruchomości.

Przeprowadzone badania terenowe oraz analiza składu gatunkowego roślin zastosowanych w przydomowych ogrodach, których obszar w dużym stopniu stanowią nadal użytki rolne potwierdziły, że współczesne - nowo powstające ogrody, niemal całkowicie utraciły funkcje produkcyjne na rzecz funkcji rekreacyjno-ozdobnych. Zjawisko to należy ocenić negatywnie, szczególnie, gdy tak jak w przypadku analizowanego obrębu ewidencyjnego Bytkowo, dotyczy ono przydomowych gruntów rolnych dobrej jakości. Jak wcześniej wspomniano, jedynie w nielicznych przypadkach w inwentaryzowanych ogrodach odnotowano obecność drzew owocowych (m.in. grusza, czereśnia, wiśnia, jabłoń) oraz niewielkich zagonów warzywno-ziołowych.

Powszechnym elementem były natomiast strzyżone trawniki, żywopłoty z roślin iglastych oraz kompozycje z roślin zimozielonych (często obcych gatunków) i ozdobne rabaty kwiatowe. Częstym zjawiskiem było także formowanie drzew i krzewów. W badanym terenie zinwentaryzowano różne odmiany następujących gatunków (poniżej podano najliczniej występujące, tworząc trzy kategorie):

- drzewa i krzewy iglaste - modrzew europejski, jałowiec (różne gatunki w odmianach), świerk kłujący, (świerk srebrny), żywotnik zachodni, żywotnik wschodni, cypryśnik, sosna kosodrzewina, sosna czarna, sosna wejmutka, jodła koreańska, cis;

- drzewa i krzewy liściaste - wierzba, magnolia, śliwowiśnia, dereń, berberys (różne gatunki w odmianach), forsycja, różanecznik (azalia), rododendron, jukka, sumak octowiec, migdałek, bukszpan, bluszcz, wrzos, krzewuszka, grójecznik, wierzba kędzierzawa, tawuła (różne gatunki w odmianach), irga, trzmielina (różne gatunki w odmianach), klon palmowy, hortensja, bez;

- rośliny ozdobne (byliny) - tulipan, hiacynt, krokus, żonkil, szafirek, róża, lawenda. 


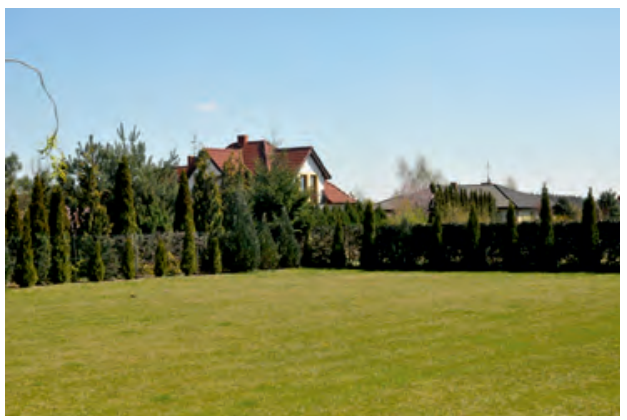

Fot. 1. Trawnik - typowe zagospodarowanie użytku rolnego na zabudowanej działce budowlanej - obręb ewidencyjny Bytkowo, gmina Rokietnica

fot. B. Maćkiewicz, M. Szczepańska

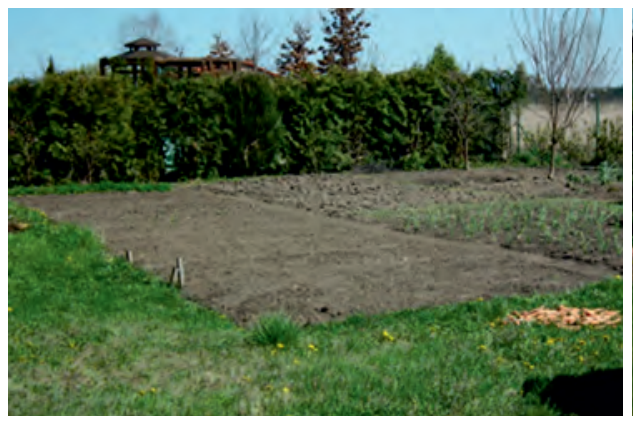

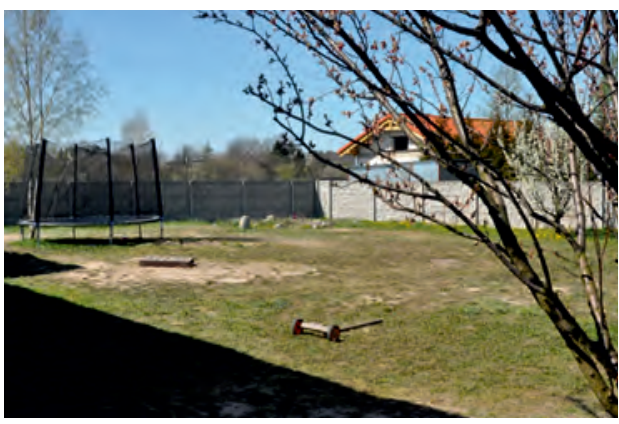

Fot. 2. Teren rekreacyjny - typowe zagospodarowanie użytku rolnego na zabudowanej działce budowlanej - obręb ewidencyjny Bytkowo, gmina Rokietnica fot. B. Maćkiewicz, M. Szczepańska

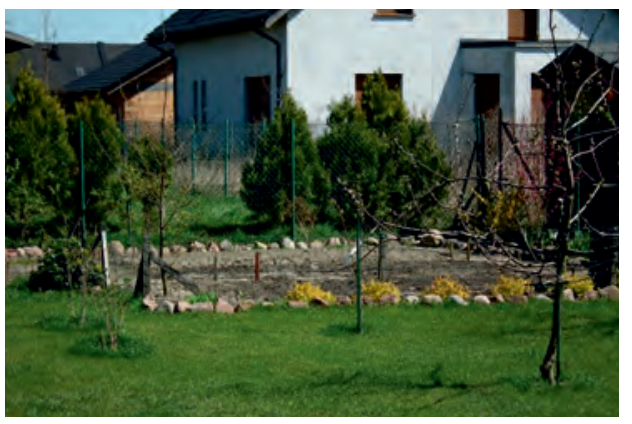

Fot. 3-4. Zagony warzywne - przykłady „nietypowego” zagospodarowania użytku rolnego na zabudowanej działce budowlanej - obręb ewidencyjny Bytkowo, gmina Rokietnica

fot. B. Maćkiewicz, M. Szczepańska

W obrębie Bytkowo odnotowano jeden, pozytywny przykład posesji, która sposobem użytkowania gruntu, doborem roślin i materiału budowlanego (drewno, cegła, kamień) oraz detalu architektonicznego (okiennice, ganek, brama) nawiązywała w nowoczesny sposób do dawnych wiejskich kompozycji ogrodowych. W ogrodzie zastosowano drzewa i krzewy owocowe (m.in. grusza, wiśnia, czereśnia, porzeczka), zagony ziołowo-warzywne, liściasty żywopłot (ligustr, buk), podokienne kompozycje kwiatowe (m.in. różanecznik, rododendron, barwinek, lawenda, szafirek), drzewa „opiekuńcze”, nie nasadzono natomiast roślin iglastych. Niemniej jednak, powyższy przepadek należy uznać za wyjątkowy, gdyż jak potwierdziły przeprowadzone badania, obecnie dominujący jest zgoła odmienny sposób zagospodarowywania. W tej sytuacji trudno mieć nadzieję, że 
niegdyś powszechna forma ogrodu wiejskiego, stosowane w nim rodzime gatunki roślin oraz sposób użytkowania, ma szansę powrócić do krajobrazu wiejskiego na zasadzie inności i odmienności od współcześnie powszechnych na obszarach wiejskich ogrodów w stylu miejskim.

\section{Podsumowanie}

Przeprowadzone badania wykazały, że na analizowanym obszarze użytki rolne wchodzące w skład zabudowanych działek budowlanych stanowią znaczący odsetek ich powierzchni - ponad $1 / 4$. Zdecydowana większość ww. użytków rolnych to dobrej jakości grunty orne - klasa IIIb, wykorzystywane głównie jako trawniki i tereny rekreacyjne. Inwentaryzacja terenu ujawniła, że jedynie na kilku działkach ewidencyjnych użytki rolne, przynajmniej częściowo, przeznaczone były pod uprawę warzyw i owoców. Oznacza to, że w zdecydowanej większości przypadków zagospodarowanie tego typu gruntów jest sprzeczne z zapisami ewidencji gruntów i budynków - gdzie wciąż widnieją one jako użytki rolne. Taki stan rzeczy, szczególnie, gdy jak w przypadku analizowanego obrębu Bytkowo, dotyczy on gruntów rolnych dobrej jakości, należy ocenić negatywnie. Badania potwierdziły ponadto niemal całkowity zanik tradycyjnych elementów ogrodu wiejskiego, takich jak: sad, ogród ziołowy czy wspomniany wcześniej ogród warzywny, jak również powszechną utratę gatunków rodzimych, zwłaszcza liściastych, owocujących i kwitnących. Oznacza to, jak wcześniej podkreślał M. Uruszczak i in. (2015), że współczesne trendy w kształtowaniu przestrzeni przydomowej na terenach wiejskich, będących pod wpływem silnej presji urbanizacyjnej, są niepokojące. Zanika nie tylko funkcja produkcyjna ogrodu, którego zaczną część często stanowią grunty z formalnego i zarazem fiskalnego punktu widzenia będące użytkami rolnymi, ginie też regionalna tradycja i symbolika ogrodu wiejskiego - jego specyfika gatunkowa, kompozycyjna i funkcjonalna, a tym samym tożsamość krajobrazu wiejskiego. Szczególne obawy budzi powszechna zgoda na obserwowany stan rzeczy. Wydaje się on bowiem, nie tylko z ekonomicznego punktu widzenia, wysoce dyskusyjny. Obecnie, gdy w wielu miejscach na świecie przywraca się funkcję produkcyjną gruntów, rodzimy charakter upraw i nasadzeń, a także kwestia samowystarczalności żywieniowej nabierają coraz większego znaczenia. Z pewnością sprawie zagospodarowania użytków rolnych w polskiej przestrzeni podmiejskiej należałoby poświęcić więcej uwagi.

\section{LITERATURA}

Bański J., 2005, Przestrzenny wymiar współczesnych procesów na wsi, „Studia Obszarów Wiejskich", 9, IGiPZ PAN, PTG, Warszawa.

Baranowski B., 1964, Zarys historii ogrodnictwa wiejskiego w Polsce, PWRiL, Warszawa. 
Bogdanowski J., 1976, Kompozycja i planowanie w architekturze krajobrazu, WrocławWarszawa-Kraków-Gdańsk, Zakład Narodowy im. Ossolińskich.

Borcz Z., 2005, Zmiany w krajobrazie wsi na przełomie XX i XXI wieku, „Architektura Krajobrazu. Studia i Prezentacje", 1-2: 4-9.

Cała A., Orzechowska I., 2007, Rola ogrodu przydomowego w kształtowaniu wizerunku wsi, [w:] Gawryszewska B.J., Herman K. (red.), Ogród za oknem. Współczesny ogród przydomowy w teorii architektury krajobrazu, Wydawnictwo Ideagrafia, Warszawa: 42-45.

Chojnacka M., Wilkaniec A., 2011, Tradycyjny ogród wiejski - historia $i$ współczesne inspiracje, [w:] Drozdek M.E. (red.), Zieleń miast $i$ wsi wspótczesna i zabytkowa. Rośliny do zadań specjalnych, Oficyna Wydawnicza Państwowej Szkoły Zawodowej w Sulechowie, Sulechów-Kalsk: 193-206.

Chowaniec M., 1964, Siedlisko i zagroda w planowaniu wsi, Arkady, Warszawa.

Czechowicz M., Kozłowska E., 2004, Zmiany w zagospodarowaniu przestrzeni przydomowych na terenach wiejskich na przykładzie wsi dolnośląskich, [w:] Krajobraz i ogród wiejski, t. 2: Tradycje a wspótczesny krajobraz polskiej wsi: 63-72.

Kacprzak E., Maćkiewicz B., 2011, Wyłaczenia użytków rolnych z produkcji rolniczej w powiecie poznańskim w latach 2000-2009, [w:] Kacprzak E., Maćkiewicz B. (red.), Gospodarka rolna $w$ aglomeracji poznańskiej, Biblioteka Aglomeracji Poznańskiej 16, Wydawnictwo Naukowe Bogucki, Poznań: 61-70.

Kacprzak E., Maćkiewicz B., 2013, Farmland conversion and changes in the land-use pattern in the Poznań agglomeration in the years 2000-2009, [w:] Kołodziejczak A. (red.), „Questiones Geographicae”, 32(4): 91-102.

Kacprzak E., Staszewska S., 2009, Zmiany struktury funkcjonalno-przestrzennej jednostek osadniczych strefy podmiejskiej dużych ośrodków miejskich (na przykładzie strefy podmiejskiej miasta Poznania), [w:] Marszał T. (red.), Struktura funkcjonalna małych miast, Wydawnictwo Uniwersytetu Łódzkiego, Łódź: 51-68.

Kacprzak E., Staszewska S., 2011, Wptyw suburbanizacji na wiejskie struktury osadnicze, „Studia Miejskie”, 3: 99-112.

Kajdanek K., 2012, Suburbanizacja po polsku, Zakład Wydawniczy NOMOS, Kraków.

Lisowski A., Grochowski M., 2007, Procesy suburbanizacji. Uwarunkowania, formy i konsekwencje, Opracowanie przygotowane na zlecenie Ministerstwa Rozwoju Regionalnego, Warszawa.

Maćkiewicz B., 2007, Rynek nieruchomości niezabudowanych $w$ Poznaniu i powiecie poznańskim w latach 1995-2000, Bogucki Wydawnictwo Naukowe, Poznań.

Maćkiewicz B., 2011, Obrót gruntami niezabudowanymi w aglomeracji poznańskiej w latach 1999-2009, [w:] Kacprzak E., Maćkiewicz B. (red.), Gospodarka rolna w aglomeracji poznańskiej, Biblioteka Aglomeracji Poznańskiej, 16, Wydawnictwo Naukowe Bogucki, Poznań: 71-70-89.

Maćkiewicz B., 2016, Gospodarka gruntami, [w:] Kaczmarek T., Mikuła Ł. (red.), Koncepcja kierunków rozwoju przestrzennego Metropolii Poznań, Centrum Badań Metropolitalnych UAM, Poznań: 171-179.

Maćkiewicz B., Motek P., 2014, Wytączenia gruntów rolnych z produkcji rolnej a dochody gmin z podatku od nieruchomości, „Rozwój Regionalny i Polityka Regionalna”, 28, Bogucki Wydawnictwo Naukowe, Poznań: 69-77. 
Maćkiewicz B., Kacprzak E., 2015, Policies of farmland use in the agglomeration of Poznań, „Studia Regionalia”, 41-42: 115-128.

Majdecka-Strzeżek A., 2009, Kształtowanie i ochrona krajobrazu miejscowości z uwzględnieniem specyfiki regionalnej dla potrzeb turystyki, „Nauka, Przyroda, Technologie”, 3(1): 21-22.

Majdecki L., 2009, Historia ogrodów, t. I i II, Wydawnictwo Naukowe PWN, Warszawa.

Mitkowska A., 2009, Ogród przydomowy jako odzwierciedlenie tradycji miejsca, [w:] Gawryszewska B.J., Rothimel B. (red.), Ogród za oknem. W poszukiwaniu formy, Wydawnictwo Sztuka Ogrodu Sztuka Krajobrazu, Warszawa: 67-78.

Marks E., Połucha I., Elkhatib A.O., 2012, Współczesne trendy zagospodarowania przestrzeni przydomowej obszarów wiejskich na wybranych przykładach, „Acta Sci. Pol. Administratio Locorum", 11 (3): 185-199.

Niedźwiecka-Filipiak I., 2005, Przemiany wizerunku wsi opolskiej pod wpływem odnowy wsi, „Architektura Krajobrazu. Studia i Prezentacje”, 1-2: 18-26.

Pietrzak M., Angiel M., 2009, Tradycyjny ogród wiejski w krajobrazie Pogórzy Karpackich, [w:] Gawryszewska B.J., Rothimel B. (red.), Ogród za oknem. W poszukiwaniu formy, Wydawnictwo Sztuka Ogrodu Sztuka Krajobrazu, Warszawa: 67-78.

Plessner H., 1987, Wiejski ogród przydomowy, Zakład Wydawniczy, CRS, Warszawa.

Rozporzadzenie Ministra Infrastruktury w sprawie warunków technicznych, jakim powinny odpowiadać budynki i ich usytuowanie (Dz.U. 2015, poz. 1422).

Śleszyński P., 2016, Konferencja „,Spoleczne, gospodarcze i przestrzenne wyzwania dla polityki rozwoju Warszawy i jej obszaru metropolitalnego”, „Przegląd Geograficzny. Kronika", 88(2): 287-290.

Topolski J., 1964, Ogrodnictwo, [w:] Buszta J. (red.), Kultura ludowa Wielkopolski, t. III, Wydawnictwo Poznańskie, Poznań: 267-298.

Uruszczak M., 2012, Przemiany przydomowych ogrodów wiejskich w Małopolsce na przyktadzie Jury Krakowsko-Częstochowskiej, [w:] Infrastruktura i ekologia terenów wiejskich, Komisja Technicznej Infrastruktury Wsi, PAN, Kraków.

Uruszczak M., Myga-Piątek U., Pijanowski J., Przegon W., Nita J., Szczepańska M., Kwoczyńska B., Dzudzińska A., Koziara Z., 2015, Planowanie krajobrazu a rozwój regionalny, Wydawnictwo Uniwersytetu Rolniczego w Krakowie, Kraków.

Ustawa z dnia 27 kwietnia 2001 roku Prawo ochrony środowiska (Dz.U. 2001, nr 62, poz. 627, z późn. zm.).

Ustawa z dnia 3 lutego 1995 roku o ochronie gruntów rolnych i leśnych (Dz.U. 2015, poz. 909, z późn. zm.).

Ustawa z dnia 15 listopada 1984 roku o podatku rolnym (Dz.U. 2016, poz. 617, z późn. zm.).

Ustawa z dnia 12 stycznia 1991 roku o podatkach i opłatach lokalnych (Dz.U. 2016, poz. 716, z późn. zm.).

Ustawa z dnia 7 lipca 1994 roku Prawo Budowlane (Dz.U. 2016, nr 0, poz. 290, z późn. zm.).

Ustawa z dnia 27 marca 2003 roku o planowaniu i zagospodarowaniu przestrzennym (Dz.U. 2016, nr 0, poz. 778 , z późn. zm.).

Ustawa z dnia 16 kwietnia 2004 roku o ochronie przyrody (Dz.U. 2016, nr 0, poz. 2134, z późn. zm.).

Wójcik M., 2008, Przemiany społeczno-gospodarcze wsi aglomeracji łódzkiej w okresie transformacji ustrojowej, Wydawnictwo Uniwersytetu Łódzkiego, Łódź. 
Zaraś-Januszkiewicz E.M., Szymczak-Piątek M., Wieczorek J., 2004, Symbolika roślin i zwiqzana z nimi obrzędowość w tradycji ludowej, [w:] Janecki J., Borkowski Z. (red.), Krajobraz i ogród wiejski, t. 3: Przyrodniczy i kulturowy krajobraz wiejski, Wydawnictwo KUL, Lublin.

\section{DEVELOPMENT OF AGRICULTURAL LAND IN BUILT-UP HOUSING AREAS IN THE AGGLOMERATION OF POZNAŃ}

Summary Since the beginning of the socio-economic transformation in Poland we have witnessed a steady reduction of agricultural land. It has taken place mainly as a result of the process of taking out farmland from agricultural production to be used for investment purposes. The dominant direction of this process is to create housing areas. It concerns, to great extent, rural areas which are adjacent to big cities. As a consequence, rural areas located in agglomerations are gradually losing their character both in terms of their economic functions, the structure of residents, and the landscape. This contributes to such phenomena as excessive and irrevocable loss of agricultural land including areas of high quality soils, the development of dispersed housing, the loss of rural landscape as well as problems with establishing accurate surface used for agricultural purposes. The aim of the paper is to identify how agricultural land which remains after completion of the housing construction process within the agglomeration of Poznań is developed. Our investigation concentrated on the geodetic district of Bytkowo located in Rokietnica commune which borders with the city of Poznan from the north west. The analyses were conducted basing on data obtained from Land and Buildings Records of the Poviat Centre of Geodetic and Cartographic Documentation (the real-estate cadastre) in Poznań, Spatial Information System data and information and data collected as a result of direct inventories of the plots. Conducted research revealed that the predominant majority (85\%) of agricultural areas which constitute part of built-up housing lots are used mainly as lawns and recreational terrains. Compiled inventory of the plots demonstrated that only on a few of them the farmland was, at least partially, used for vegetable cultivation. This means that in great majority this type of land is used in a way which is incompatible with the cadastral information - where these areas still function as farmland. The research confirmed almost complete disappearance of traditional elements of rural gardens such as orchards, herbal gardens or already mentioned vegetable gardens and, what follows, a loss of indigenous plants especially deciduous, flowering, and productive trees and bushes. These contemporary trends in shaping backyard space located in rural areas experiencing high urbanisation pressure are worrying. The gradual disappearance of tradition and symbolism of rural garden - its plant specificity, composition and function and, as a consequence, its rural landscape identity is evident. Particular worries are related to the lack of awareness of tradition or, even worse, a conscious attempt to break with this 
rural tradition as it is perceived negatively in the sense that it is identified with backwardness of the countryside. The tendency to copy urban standards is further reinforced by the wide availability of plants especially of foreign origin, building and construction materials as well as lack of time for cultivation practices. Varied and all-year-round supply of fruit, vegetables and herbs and their processed products contributes significantly to the vanishing of time-consuming backyard vegetable gardens and orchards.

Keywords Agricultural land, suburbanization, built-up housing areas, rural landscape.

Professor Juan José Ruiz Lendínez Geodésica y Fotogrametría Departamento de Ingeniería Cartográfica

Universidad de Jaén (España) e-mail: lendinez@ujaen.es

Dr Barbara Maćkiewicz Instytut Geografii Społeczno-Ekonomicznej i Gospodarki Przestrzennej Wydział Nauk Geograficznych i Geologicznych Uniwersytet im. Adama Mickiewicza w Poznaniu e-mail: basic@amu.edu.pl

Dr inż. Magdalena Szczepańska Instytut Geografii Społeczno-Ekonomicznej i Gospodarki Przestrzennej Wydział Nauk Geograficznych i Geologicznych Uniwersytet im. Adama Mickiewicza w Poznaniu e-mail: szmagda@amu.edu.pl 